\title{
THE PLAINS AND THE ROCKIES
}

OST Cause Press has published, on Microcard, every item we have been able to find from the Wagner-Camp bibliography Plains and Rockies. We continue to search.

The first edition of H. R. Wagner's bibliography came out in 1920 after some 27 years' work of compilation. In 1937 a second edition was printed. From 1922 C. L. Camp shared the work with Mr. Wagner and revised the third edition. Included in this bibliography are books, magazine articles, Federal documents, some compilations and newspaper items of personal experience written between 1800 and 1865. Geographical scope includes the region lying between the Missouri River and the Sierra Nevada Cascades, from Mexico to the Arctic (with omission of Texas and what is now Western Louisiana - and in Canada everything East of the Red River).

The historical material we have assembled here on Microcard is essential to the student of pioneer history.

Approximately 537 volumes, postpaid ..............\$5,280.00*

*10\% discount on orders received on or before March 18, 1967. Duplicates of items already in library collections may be returned for credit within six months after receipt of shipment. 


\section{CHICAGO AREA "LIBRAS"}

Eight Chicago-area private colleges have initiated a sharing program which will give their students access to combined library holdings of over half a million volumes and thirtyfive hundred periodicals and journals.

The eight college libraries, all west of Chicago, have been working together since December 1965. The aim is to perfect a system whereby a student from any one of the colleges could quickly draw on the resources of any of the other participating libraries for study and research material.

The participating colleges are Aurora College; North Central College, Naperville; St. Procopius College, Lisle; St. Dominic College, St. Charles; George Williams College, Downers Grove; Maryknoll College, Glen Ellyn; Elmhurst College; and Wheaton College. Librarians from these colleges have organized a group called Libras to work out details of the cooperative program.

Robert Golter, librarian at Wheaton College, and president of Libras, explained the reasoning for the sharing program. "The student at a small private college is sometimes handicapped by limited library resources on campus, particularly in a day when academic excellence emphasizes honors programs and independent study. Each of the eight libraries in this program has developed specialized collections in different interest areas, and through this kind of cooperation we can make a much wider variety of resources available for students than any one library could hope to do on its own."

Additional cause for cooperative lending, according to Golter, is that libraries can begin to coordinate their acquisitions of periodicals and books to avoid unnecessary duplication. Each library will continue acquiring frequently called-for periodicals, but more specialized holdings will be kept by whichever college library has the most need for them.

"This allows us to purchase a greater variety of books and periodicals without substantially increasing the cost, because we know that if we don't have a particular journal it is available through another cooperating library," says Golter.

Initially the project entails a combined listing of all periodicals held by the libraries. To be completed within the next month or two, copies of a Union List of Periodicals will be provided for each Libras library. A student or professor seeking information on a particular subject will be able to consult the list to determine the location of journals which have pertinent articles. If some of these journals are held by other colleges, he will request his librarian to telephone the respective libraries for photocopies of desired material. The other libraries will copy the articles immediately and mail them to the

student's library, where most often he can pick them up the next day.

The Illinois state library, which is in favor of interlibrary sharing, has aided the eight colleges in preparing the Union List so that the data can be updated easily. The Libras organization is investigating the possibility of installing facsimile transmission equipment in each library, so that photocopies could be transmitted while the student waits.

A similar listing for all books currently being acquired in the eight libraries is expected to be instituted early in 1967. By that time the librarians hope to have a system worked out to enable students to withdraw volumes directly. Currently students may request books from other libraries through their own college librarian.

"Less frequently will a student have to worry that he won't be able to find a book or magazine that he needs for his studies, because his own library doesn't have it," Golter said. "The eight libraries in this program are adding close to thirty thousand new books each year to their collection, and will be able to offer the student varied and significant materials for study and research."

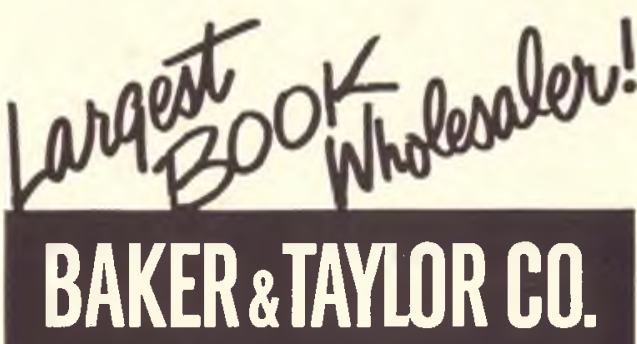

IN EACH OF OUR 3 MAJOR WAREHOUSES: 1,500,000 books... 100,000 different titles from 1,200 publishers... fastest, most complete and accurate book service.

EASTERN DIVISION

HILLSIDE. N.J. 07205 Telephone: 201-923-3200

N.Y C Tel: BArclay $7-8470$

MIDWEST AND SOUTHERN DIVISION MOMENCE, ILLINOIS 60954 Telephone: $815 \cdot 472 \cdot 2444$ Chicago Tel: $346-4074$

BOOK INSPECTION CENTER The Baker \& Taylor Co. of Texas, Inc. 1701 W. Gray St., Houston, Texas 77019 